California Natural History Guides: 12

\title{
BUTTERFLIES \\ OF THE
}

SAN FRANCISCO BAY REGION

\author{
BY \\ J. W. TILDEN \\ Illustrations by Gene M. Christman
}

UNIVERSITY OF CALIFORNIA PRESS

BERKELEY, LOS ANGELES, LONDON 
UNIVERSITY OF CALIFORNIA PRESS

BERKELEY AND LOS ANGELES, CALIFORNIA

UNIVERSITY OF CALIFORNIA PRESS LTD.

LONDON, ENGLAND

(c) 1965 BY THE REGENTS OF THE UNIVERSITY OF CALIFORNIA SECOND PRINTING, 1974 LSBN : 0-520-01268-2

LIBRARY OF CONGRESS CATALOG CARD NUMBER: 64-24888 PRINTED IN THE UNITED STATES OF AMERICA 